THEMATIC SECTION: THE RIGHT TO PUBLIC EDUCATION, DEMOCRACY, AND SOCIAL

STRUGGLES

\title{
Higher education in times of neoliberal adjustment and loss of rights
}

\author{
Kátia Regina de Souza Lima ${ }^{1}$ \\ https://orcid.org/0000-0002-2603-3690 \\ ${ }^{1}$ Fluminense Federal University, Department of Social Work of Niterói, Graduate Program in Social Work and Regional Development, \\ Niterói, RJ, Brazil.
}

\section{Higher education in times of neoliberal adjustment and loss of rights}

Abstract: This article presents some of the reflections made in a research group of the Graduate Program in Social Work of the Fluminense Federal University in the State of Rio de Janeiro, Brazil. The reflections are based on bibliographic research and document analysis regarding the different phases of neoliberal counterrevolution in Brazil, discussing the permanent fiscal adjustment policy that aims to ensure the payment of public debt - and its consequences in public spending on higher education. The conclusions indicate that government actions lead to deepening the precariousness of public universities, expansion of the privatization of higher education, and regression of workers' rights, suggesting the rise of a new stage of the class struggle in the country.

Keywords: neoliberal counterrevolution. fiscal adjustment. higher education

Submitted on December 03, 2018. Approved on April 16, 2019. Reviewed on June 03, 2019.

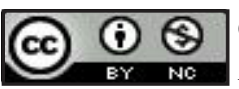

(C) The Author(s). 2019 Open Access This article is distributed under the terms of the Creative Commons Attribution-NonCommercial 4.0 International License (http://creativecommons.org/licenses/by-nc/4.0/), which permits use, distribution, and reproduction in any medium, since it's for non-commercial purposes, and provided you give appropriate credit to the original author(s) and the source, provide a link to the Creative Commons license, and indicate if changes were made. 


\section{Introduction}

This article is based on bibliographic research and document analysis, presenting reflections carried out in a research group of the Graduate Program in Social Work of the Fluminense Federal University, in Niterói, Rio de Janeiro, Brazil. The study examines the political and social meanings of the federal government actions in a period of neoliberal counterrevolution, observing the policies of fiscal adjustment and their implication in public higher education. This issue is particularly urgent and necessary, considering the context where social rights and the public university (as a privileged locus of the production of scientific and technological knowledge), are under threat in Brazil.

The first section of the article addresses the different phases of neoliberal counterrevolution in Brazil: the phase of the administration by Presidents Lula da Silva and Dilma Rousseff (2003-2016), characterized by the policy of class conciliation; the post-impeachment phase, with the government of President Michel Temer (2016-2018), marked by the deepening of economic inequalities and attacks on workers' rights, gained after years of struggles. This critical approach adopted in the analysis of these phases is supported by the work of the intellectual and activist Florestan Fernandes. The use of Fernandes' analytical guidelines helps to understand the particularities of counterrevolution in a country marked by the ultra-conservative nature of its native bourgeoisie, as the activist suggested (Fernandes, 1980).

The section 'higher education crossing a bridge' offers an analysis of the regression of rights carried out under the leadership of the party 'Brazilian Democratic Movement' (MDB), which took office after the impeachment of President Rousseff and ruled the country from 2016 to 2018. The study examined three documents: I) Uma Ponte para o Futuro (A Bridge to the Future) (Fundação Ulysses Guimarães \& Partido Do Movimento Democrático Brasileiro, 2015); II) Constitutional Amendment (EC) 95 (Emenda Constitucional No. 95, 2016), enacted on December 15, 2016, originated from the Bill 241 (Chamber of Deputies) on public spending through constitutional amendment (PEC), and Bill 55 (Senate); and III) Travessia Social: uma ponte para o futuro (The social crossing: a bridge to the future) (Fundação Ulysses Guimarães \& Partido Do Movimento Democrático Brasileiro, 2016).

Finally, the article evaluates the political and social meanings of the permanent fiscal adjustment, and of the policies that have represented the regression of social rights. The discussion reflects the impacts of these policies regarding issues such as privatization and commercialization of higher education, which serves the interests of the capital, ensuring profits in a promising educational market, and the conformation of minds and hearts to the bourgeois project of sociability.

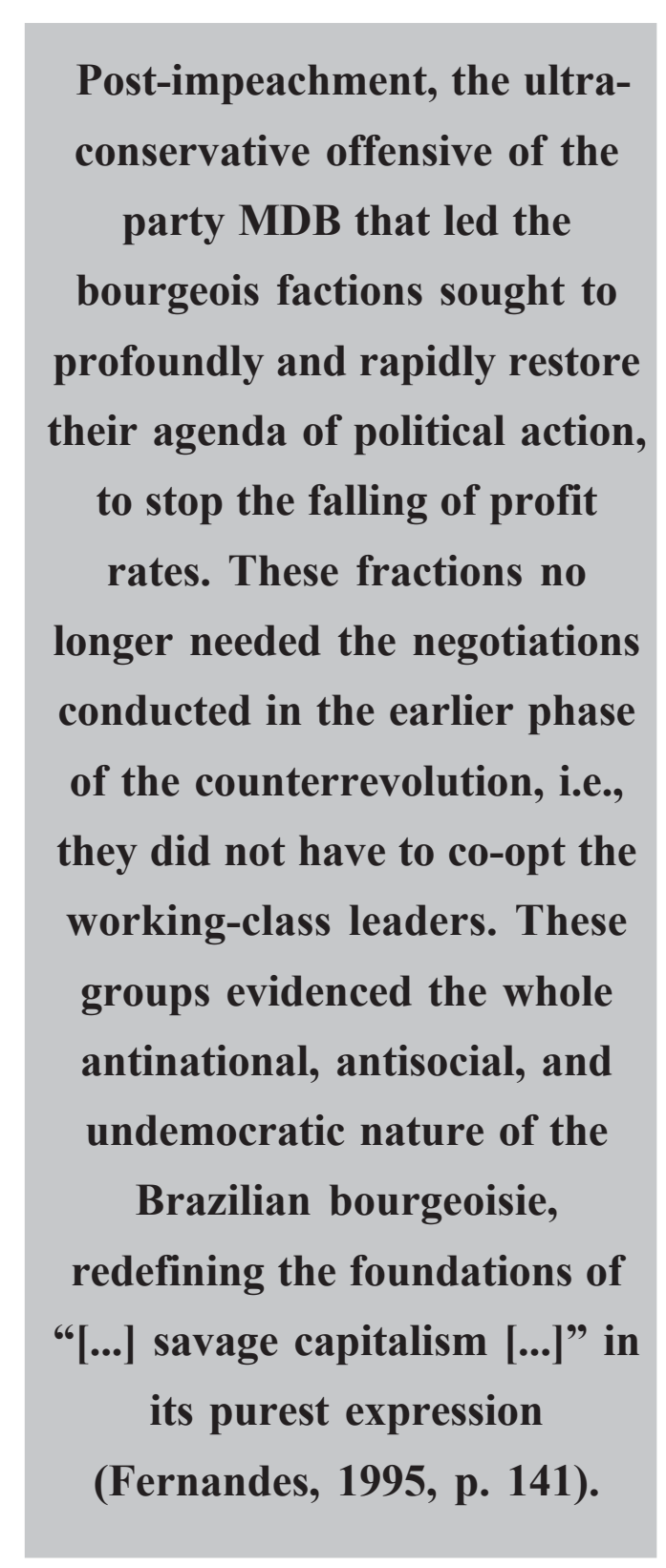

\section{Dependent capitalism, permanent fiscal adjustment, and conterrevolution in Brazil}

When analyzing the development of capitalism in Brazil, Florestan Fernandes $(1975$, p. 110) states that the concept represents a "composite pattern of bourgeois hegemony" that historically associates the bourgeoisie with imperialism and the most archaic sectors of the Brazilian economy, operating the dual pattern of expropriation of the economic surplus. Thus, the wealth collectively produced by the workers in 
Brazil is divided between the international and the national bourgeoisie as two sides of the same domination project. Therefore, the Brazilian bourgeoisie is not a weak class. It has a relative autonomy to negotiate the terms of its dependence of imperialist countries, as they needed, and need strong partners in the periphery of capitalism to consolidate their hegemonic project (Sampaio Júnior, 2001).

This political composition among conservative sectors accommodates the most archaic interests of class fractions. The exclusion or pursuit of passive or active consensus by workers are not historically dated phenomena, but inherent characteristics of the bourgeoisie of the dependent capitalist countries. Thus, the cited 'composite pattern of bourgeois hegemony,' and the appropriation of the economic surplus by international and Brazilian bourgeoisie (dual pattern of expropriation), are constitutive, structuring features of class domination. This indicates the ultra-conservative profile of the Brazilian bourgeoisie and its antisocial and anti-national actions of increasing exploitation of the workforce; exporting part of the economic surplus to imperialist countries, privileging the profitability of capital, and intensifying economic, political, and social inequalities.

In this analytical framework, the systematic crises of capitalism are unsolvable contradictions of the system. They make bourgeois counterrevolution - understood as a set of political and economic actions carried out by the bourgeoisie to guarantee the reproduction of its sociability project - a continual process that can materialize in repressive and authoritarian practices. Sometimes it is transformed and 'recycled' through projects of restricted democracy, according to the historical and spatial features of the class struggle (Fernandes, 1980). In a country marked by a dependent capitalist insertion in the world economy, the composite pattern of bourgeois hegemony, and the dual pattern of expropriation of the economic surplus, the characteristics defining the bourgeois counterrevolution are well defined.

Florestan Fernandes (1976, p. 362), observes that there are two forms of bourgeois counterrevolution in Brazil, a "hot" and a "cold." The first expresses violent action associated with the bourgeois military regime and autocratic state. The cold counterrevolution is connected to the existence of " "safe' and 'constructive' phases of counterrevolution." (Fernandes, 1976, p. 347). Cold counterrevolutionary actions demonstrate the capacity of the Brazilian bourgeoisie to broaden the political participation of workers without endangering the essence of capitalist exploitation/domination.

The cold counterrevolution of the Brazilian bourgeoisie adopted a strategy with three fundamental aspects. First, establishing a pact of domination between the bourgeoisie fractions, considering its two faces: Brazilian and international. The second aspect is building alliances with the working class union and partyrelated bureaucracies. Finally, the third aspect is limiting the workers' struggles to constitutional and parliamentary action, encouraging the bourgeoisization of their union and party-related bureaucracies by defending the policy of class conciliation.

It is possible to say that the cold counterrevolution was underway in Brazil from 2003 to 2016, based on the configurations in the class struggle at that time. During this period the government used strategies that resemble the words of Fernandes (1991, pp. 82-83): "it is enough to incorporate a broader part of the workingclass avant-garde and the union or party-related bureaucracies into the middle classes, to convert them to bourgeois and walking knights of bourgeois democracy".

The process of recycling the neoliberal model carried out during these years could be observed since the beginning of the Lula da Silva administration:

The Workers' Party government did not dare to face the external and internal interests supporting the established order. The party became the opposite of what its constituents expected. It disregarded its ideological foundations and chose for the continuation of orthodox adjustment, submitting the economic policy to the guidance of the financial market and the international financial bodies. At the center of this strategy was the need to regain the trust of the international capital, an essential condition - in the official discourse - to make it possible to recycle foreign and domestic debts and thus avoid the country's financial entrenchment. The fundamental drivers of the country's economic agenda - the absolute priority given to stable inflation when conducting the economic and exchange rate policy, the emphasis on growing trade surplus to cover foreign debt, the permanent fiscal adjustment to honor public debt, the opening of big business to big capital, and the systematic attack on workers' rights - reveal a logic that is predatory, rentier and mercantile, that governs the economic policy (Sampaio Junior, 2017, p. 52).

The policy of class conciliation is the manifestation of the preventive and prolonged counterrevolution in Brazil in the period 2003-2016. This unfolding of the counterrevolutionary process was possible because the Brazilian bourgeoisie combined repression with broadening the working class's political participation, expanding the limits of a legal and formal political equality that coexisted with socioeconomic inequalities (Dias, 2004). The referred expansion was carried out by the working class' union and political leaders, organized in the 
Workers' Party (PT) - from Presidents Lula da Silva to Dilma Rousseff. During the period from 2003 to 2005, the PT was in partnership with the Liberal Party (PL), with Vice-President José Alencar; from 2005 to 2010 in partnership with the Brazilian Republican Party (PRB) also with vice-President José Alencar; and finally from 2011 to 2016 with the party MDB, with vice-president Michel Temer).

The public debt represents the 'colonial tax,' and this burden and the logic of permanent fiscal adjustment constituted the political-economic foundation of the main actions of the Federal Government in the period 20032016. This materialized the composite pattern of bourgeois hegemony and the dual pattern of expropriation of the historically prevailing economic surplus in Brazil, shown in Tables 1 and 2.

Table 1 - Relationship between debt service public spending and public spending with other areas in the period 2003-2005

\begin{tabular}{c|c|c}
\hline Year & $\begin{array}{c}\text { Debt service public } \\
\text { spending (BRL in billions) }\end{array}$ & $\begin{array}{c}\text { Public spending with other areas (health, education, social services, agriculture, public } \\
\text { safety, culture, urban development, housing, sanitation, environmental management, } \\
\text { science and technology, land organization, energy, and transportation) (BRL in billion) }\end{array}$ \\
\hline 2003 & 132 & 70 \\
2004 & 124 & 65 \\
2005 & 139 & 99 \\
\hline
\end{tabular}

Source: Coordenação da “Auditoria Cidadã da Dívida”(2004,2005, 2006a).

The same policy that privileges public debt service payment and tax adjustment are identified in Table 2, showing data from the period 2006-2017.

Table 2 - Percentage of the Orçamento Geral da União (Brazilian Federal Budget) spent on public debt service payment, in comparison to the percentage spent on other areas (health, education, and social services) between 2006 and 2017

\begin{tabular}{c|c|c|c|c}
\hline Year & $\begin{array}{l}\text { Percentage of the Federal } \\
\text { Budget spent on the public debt } \\
\text { service payment }\end{array}$ & $\begin{array}{c}\text { Percentage of the Federal } \\
\text { Budget spent on health }\end{array}$ & $\begin{array}{c}\text { Percentage of the Federal } \\
\text { Budget spent on education }\end{array}$ & $\begin{array}{l}\text { Percentage of the Federal } \\
\text { Budget } \\
\text { services }\end{array}$ \\
\hline 2006 & $40 \%$ & $4,72 \%$ & $1,96 \%$ & $2,64 \%$ \\
2007 & $30,59 \%$ & $5,17 \%$ & $2,58 \%$ & $3,01 \%$ \\
2008 & $30,57 \%$ & $4,81 \%$ & $2,57 \%$ & $3,08 \%$ \\
2009 & $35,57 \%$ & $4,62 \%$ & $2,88 \%$ & $3,09 \%$ \\
2010 & $44,93 \%$ & $3,91 \%$ & $2,89 \%$ & $2,74 \%$ \\
2011 & $45,05 \%$ & $4,07 \%$ & $2,99 \%$ & $2,85 \%$ \\
2012 & $43,98 \%$ & $4,17 \%$ & $3,34 \%$ & $3,15 \%$ \\
2013 & $40,30 \%$ & $4,29 \%$ & $3,70 \%$ & $3,41 \%$ \\
2014 & $45,11 \%$ & $3,98 \%$ & $3,73 \%$ & $3,08 \%$ \\
2015 & $42,43 \%$ & $4,14 \%$ & $3,91 \%$ & $3,05 \%$ \\
2016 & $43,94 \%$ & $3,90 \%$ & $3,70 \%$ & $3,02 \%$ \\
2017 & $39,70 \%$ & $4,14 \%$ & $4,10 \%$ & $3,35 \%$ \\
\hline
\end{tabular}

Source: Coordenação da “Auditoria Cidadã da Dívida”(2006b, 2008, 2009, 2010),Auditoria Cidadã da Dívida(2011), Núcleo Mineiro da Auditoria Cidadã da Dívida (2012) andAuditoria Cidadã da Dívida (2014, 2015a, 2015b, 2017, 2018).

In the Brazilian political and economic context, influenced by the impacts of the crisis of the capital that aggravated in the second half of $2008^{1}$, although the federal government maintained the policy of serving the capital $^{2}$ - emphasizing in its agenda the issue of fiscal adjustment and working on a type of criminalization of social struggles ${ }^{3}$, it was subject to pressure coming from new domestic disputes, marked by the increase in social effervescence in 2013: 
Polarized between big capital, which demands greater austerity in economic policy to stabilize the Real threatened by the risk of capital flight - and the multifaceted demonstrations of Brazilian youth, which demanded a complete inversion in economic policy, the PT government lost its strategic position as a reliever of class struggle. The pact for power that brought PT to the federal government's office expired (Sampaio Junior, 2017, p. 180).

By mid-2016, the exhaustion of a phase of neoliberal counterrevolution was announced. Fractions of the Brazilian bourgeoisie led by large contracting and agribusiness companies, as well as by the capital market, operated a classic way the capital uses when facing crises: the impeachment, which is a legal instrument provided in the Brazilian Federal Constitution, was carried out even though there was no evidence of misconduct on the part of President Rousseff. The political crisis brought about by the end of a phase of preventive and prolonged counterrevolution was the exhaustion of the policy of apparent conciliation (of the irreconcilable) class interests. It was a question of "defining who the most accredited political operator would be to manage Brazil's adjustment to the new demands of capital, international and national, in times of crisis." (Sampaio Junior, 2017, p. 245).

Post-impeachment, the ultra-conservative offensive of the party MDB that led the bourgeois factions sought to profoundly and rapidly restore their agenda of political action, to stop the falling of profit rates. These fractions no longer needed the negotiations conducted in the earlier phase of the counterrevolution, i.e., they did not have to co-opt the working-class leaders. These groups evidenced the whole antinational, antisocial, and undemocratic nature of the Brazilian bourgeoisie, redefining the foundations of "[...] savage capitalism [...]" in its purest expression (Fernandes, 1995, p. 141).

From 2003 to 2016, there was a counterrevolutionary process led by the class coalition policy. In 2016 Brazil entered a new phase of preventive and prolonged counterrevolution led by the most aggressive and conservative fractions of the bourgeoisie in their struggle for their individual interests under the direction of the party MDB. This article analyzes three central documents of the Federal Government. They present fiscal adjustment, the payment of public debt service, and the reduced spending on public policies. The documents are Uma Ponte para o Futuro (A Bridge to the Future); Constitutional Amendment (EC) 95 (Emenda Constitucional No. 95, 2016), enacted on December 15, 2016, originated from the Bill 241 (Chamber of Deputies) on public spending through constitutional amendment (PEC), and Bill 55 (Senate); and Travessia Social: uma ponte para o futuro (The social crossing: a bridge to the future). Based on the analysis of these documents, this study reflects on changes made to policies for Higher education during the past few years in Brazil.

\section{Higher education crossing a bridge}

The examination of the state and higher education counterreform (Behring, 2003; Lima, 2007), as observed in Tables 1 and 2, shows that the priority of paying the public debt service over the investing in social areas and public services, especially health, education, and social services is not something new. It started in the phase of neoliberal counterrevolution established on August 31, 2016, when President Michel Temer took office. The economic tripod: fiscal adjustment; payment of public debt service; and reconfiguration of public policy financing (including funding higher education) is a structuring dimension of the political agenda of neoliberalism in Brazil and worldwide (Antunes, 2005).

The variation between the two phases of neoliberal counterrevolution in Brazil (2003-2016 and 20162018 ) is in the equilibrium of this agenda. After the impeachment and end of the pact between the different factions of the bourgeoisie and the working-class leaders in the union and political parties that had been converted to the bourgeois order (Iasi, 2006), the new group of power seeks to maintain the historically prevailing policy of self-privilege in the country.

It is in this context that the document entitled "A Bridge to the Future," prepared by the Ulysses Guimarães Foundation and MDB party, was published in October 2015. The document is presented as a Government Program aimed at the development of the Brazilian economy facing the fiscal crisis generated by public spending and the paralysis of private investments. According to the document, the role of the state is to "distribute the right incentives for private enterprises and to manage in a rational and balanced manner the distributive conflicts within society." (Fundação Ulysses Guimarães \& Partido do Movimento Democrático Brasileiro, 2015, p. 4). Therefore, the State is conceived as an actor that promotes private initiatives and a driver of fiscal adjustment, because "Without a permanent adjustment that indicates a lasting balance of public accounts, the economy will not resume its growth and crisis should aggravate." (Fundação Ulysses Guimarães \& Partido do Movimento Democrático Brasileiro, 2015, p. 5). 
The document criticizes public expenditures approved under the Federal Constitution of 1988, especially mandatory expenditures or constitutional bindings, and social security benefits. In this sense, the text announces the political agenda of President Temer's government: I) the deepening of the policy of public debt service payment, to the detriment of spending on public policies; II) the untying of the federal government's revenues, especially of public health and education expenditures; and III) the social security counterreform ${ }^{4}$.

The plan claims the absolute autonomy of the Federal Government in the organization of the annual federal budget in order to ensure fiscal adjustment, that is, "breaking established constitutional links, as in the case of spending on health and education" (Fundação Ulysses Guimarães \& Partido do Movimento Democrático Brasileiro, 2015, p. 9) and the end of automatic readjustments, either for wages or social security benefits, eliminating the indexation of any benefit to the minimum wage value and defending the need to "[...] increase the minimum retirement age so that people spend more time working and contributing, and less time retired." (Fundação Ulysses Guimarães \& Partido do Movimento Democrático Brasileiro, 2015, P. 11).

The agenda's guidelines say that the State's actions should prioritize privatization of strategic areas of the country; reducing tariffs for the private sector and establishing public-private partnerships, complementing the provision of public services. The policies presented in the document "A Bridge to the Future," released in October 2015, were materialized by the approval by the Federal Senate, on December 13, 2016, of PEC 55 (PEC of Public Spending), current Constitutional Amendment No. 95 (Emenda Constitucional No. 95, 2016) and the document entitled "The Social Crossing: A Bridge to the Future."

The Constitutional Amendment (EC) 95/2016 (Emenda Constitucional No. 95, 2016) was enacted after being passed in the House as the bill of a constitutional amendment (PEC) 241 and in the Senate as PEC 55. The amendment established the new tax regime, limiting public spending for twenty years. This tax regime entails the freezing of public investment in public policy as it repeals the linking of health and education expenditure to the percentages of the Union's net revenue. As a result, public investment in health and education will, in real terms, have the same values as 2017, disregarding the growth of the Brazilian population and the social demands for expanding access to public health and education. In addition to the freeze on the allocation of public funds for public policies, EC 95/2016 freezes salary increases for civil servants and public tenders. Despite working-class struggles against PEC approval, it was enacted on December 15, 2016.

In the same political direction, the document entitled "The Social Crossing: ABridge to the Future," prepared by the Ulysses Guimarães Foundation and the party MDB (2016), was released in 2016, presenting the Federal Government's policy for social programs. The document reveals the development-dependent pattern associated with the dual pattern of expropriation of economic surplus and the composite pattern of bourgeois hegemony, expressed in Brazil's role in the world economy as an exporter of mineral and agricultural commodities. It is also expressed in the state's role as the driver of the legal framework that operates the labor counter-reform and the revision of the tax system, to serve the economic interests of international and local private partners.

According to the document, the country lives two vicious circles: the issue of the fiscal balance and the relationship between the fiscal situation and social policies. The defense of the fiscal adjustment policy to guarantee the payment of public debt and the freezing of public spending for public policies and services is associated with the defense of focusing on social policies to serve the poor. To confront the two vicious circles, the document proposes three articulated actions: "seek fiscal balance, resume growth, and expand good social policies" (Fundação Ulysses Guimarães \& Partido do Movimento Democrático Brasileiro, 2016, p. 6). Thus, the cut in the allocation of public funds for public policies and the favoring of private-sector movement in the most profitable areas (including higher education), were measured at the basis of President Temer's policy agenda. A new phase in the counterreform of the Brazilian state is born in this context, because:

The state should transfer to the private sector everything possible in terms of infrastructure. . . A new beginning in the State's relations with private partner companies is essential for the country's economy (Fundação Ulysses Guimarães \& Partido do Movimento Democrático Brasileiro, 2016, p. 17).

The analysis of the three documents indicated above highlights the new features of the class struggle in Brazil in the current phase of neoliberal counterrevolution. It is possible to observe the ultra-conservative nature of the Brazilian bourgeoisie and its antisocial and anti-national actions of increasing exploitation of the labor force; exporting part of the economic surplus to the imperialist centers; privileging the private sectors and intensifying economic, political and social inequalities, because "the bourgeoisie of an underdeveloped capitalist society concentrates the best of its energies, talent and creative capacity in the struggle for its economic survival" (Fernandes, 1968, p. 90).

The higher education counterreform occurs in this broader context of profound changes guided by the connection between fiscal adjustment, public debt service payment, and regression of social rights. The 
privatization of higher education in Brazil is a phenomenon that happened over time, particularly in the years marked by neoliberal governments, but including the period 2003-2016 (under the government of the Workers' Party), as shown by data from the Higher Education Census (Instituto Nacional de Estudos e Pesquisas Educacionais Anísio Teixeira, 2011, 2016). In 2010, the last year of President Lula da Silva, out of 2,377 higher education institutions (HEIs), 278 were public, and 2,099 were private. The number of undergraduate enrollments shows a majority of students in private institutions: from a total of 6,379,299 students enrolled, 1,643,298 were undergraduate students in public HEI, while 4,376,001 were enrolled in private institutions (Instituto Nacional de Estudos e Pesquisas Educacionais Anísio Teixeira, 2011).

In the same period (2003-2010), actions such as the University for All Program (ProUni) (Law 11096/ 2005) (Lei No. 11.096, 2005) and, especially, the Student Financing Fund (FIES) (Law 10260/2001) (Lei No. $10.260,2001)$ were central strategies to the strengthening private higher education. The strategies led to privatization and marketization, as they facilitated the advance of private sector participation in total enrollment and HEIs, opening a market niche for the expansion of for-profit educational institutions.

Leher (2010) looks at how ProUni materializes the guidelines of international capital agencies, especially the International Monetary Fund and the World Bank, with the acquiescence of the Ministry of Finance. The author observes that "ProUni is a program for buying places in private institutions through the worst use of public funds: the tax exemptions - the most obscure in terms of social accountability." For young workers, ProUni represents access to higher education, but such access occurs mostly in private HEIs, devoid of research policy, and the critical and creative production of knowledge. For entrepreneurs in the field of education, however, the Program represents a valuable solution to address the default in the payment of tuition fees by exempting a set of taxes: Contribution to Social Security Financing (Cofins); Contribution to social security systems (PIS/PASEP); Social Contribution on Net Income (CSLL) and Corporate Income Tax (IRPJ).

Based on the same theoretical foundation, Queiroz (2015) analyzes how FIES responded to the demands of the private higher education sector for different forms of financing, with government funding. The author highlights the set of changes made in the FIES during the period 2003-2010, pointing out that these changes intensified with Law 12202/2010 (Lei No 12.202, 2010), providing on the expansion of private-sector enrollment by creating rules to integrate this sector in the ProUni program.

In the period 2011-2016, the logic of privatizing higher education was maintained, as evidenced in the 2016 Higher Education Census (Instituto Nacional de Estudos e Pesquisas Educacionais Anísio Teixeira, 2016). Of the 2,407 HEIs, 296 were public, and 2,111 were private. Among private HEIs, 88.4\% were colleges. Regarding the number of undergraduate enrollments, "Private HEIs have a $75.3 \%$ share $(6,058,623)$ in total undergraduate enrollments. The public HEI, therefore, offers $24.7 \%(1,990,078)$ of the places." (Instituto Nacional De Estudos E Pesquisas Educacionais Anísio Teixeira, 2016, p. 5).

The policy of strengthening the private sector, considering the significant increase in private HEIs in that period, was driven by changes in FIES, especially through Law 12.513/2011 (Lei No 12.513,2011), which included the possibility of financing individual and collective professional and technological education students through companies. These changes in legislation led to the creation of two new modalities: "FIES Técnico" and "FIES Empresa." Analyzing the public resources allocated in the Annual Budget Law (LOA) in 2013, Queiroz (2015, p. 52) states that:

In 2013, the federal budget (LOA) anticipated allocating R \$ 1,644,604,823.00 (one billion, six hundred and forty-four million, six hundred and four thousand, eight hundred, and twenty-three reais) to FIES. However, President Dilma's government directed R \$5,596,506,179.43 (five billion, five hundred and ninety-six million, five hundred and six thousand, one hundred and seventy-nine reals and forty-three cents), investing 340.29 $\%$ of the amount anticipated.

The strengthening of the private sector as a general guideline for higher education policy was maintained in Law 13005/2014 (Lei No 13.005, 2014), which approved the National Education Plan (PNE) 2014-2024. The PNE goals 12, 13, and 14 deal, respectively, with the increase in enrollment in high education, the qualification of the faculty, and the increase in the number of enrollments in master and doctorate programs. Strategies to achieve the goals are related to the expansion and political-pedagogical restructuring of the REUNI Program; the expansion of FIES for undergraduate and graduate (master and doctorate) studies, including distance learning; the improvement of the National Higher Education Evaluation System (Sinaes); and the expansion of Distance Learning (ODL) through the Open University of Brazil (UAB) (Coletivo de Estudos em Marxismo e Educação, 2016; Lima, 2015; Minto, 2018).

The PNE 2014-2024 creates the legal framework for the consolidation of FIES by expanding it to distance undergraduate and graduate (master and doctorate) programs, in line with Normative Ordinance 15 of July 1 , 
2014 (Portaria No 15, 2014), which expanded FIES to the masters, professional masters, and doctorate programs recommended by the government agency CAPES. In addition to these aspects, the 2014-2024 PNE Goal 20 (providing on expansion on public investment in education), indicates that the country should spend $10 \%$ of the GDP in education in 10 years (Lei No 13.005, 2014). When analyzing the content of this goal with the indication of FIES as a source of higher education funding, it is evident how the 2014-2024 PNE favors public subsidies for the private education sector. Strategy 12.6 aims to expand funding through FIES - according to Law 10260/2001 (Lei No. $10.260,2001$ ) - with the constitution of a collateral financing fund to progressively eliminate the requirement of a guarantor to process the student loan; and strategy 12.20 proposes to expand, within the scope of FIES and ProUni - according to Law 11096/2005 (Lei No. 11.096, 2005) -, the provision of funding to students regularly enrolled in on-site or distance higher education programs offered by private HEI (Lei No 13.005, 2014).

The privatizing logic that characterized the period 2003-2016 was expanded in President Temer's government (2016-2018). As mentioned earlier, the economic tripod - fiscal adjustment privileging the public debt service payment; the reduction of public spending on public policies and services (including on higher education); and the strengthening of the private sector using public fund - form the guidelines of the counterreform of higher education. According to information from the National Association of Directors of Federal Higher Education Institutions (ANDIFES):

The 2017 budget has already represented a significant cut compared to 2016 (nominal $6.74 \%$ in the current cost spending, $10 \%$ in the Reuni expansion program, $40.1 \%$ in capital, $3.15 \%$ in the National Student Assistance Program and plus $6.28 \%$ inflation in the period); ... The budget for 2018 maintains the 2017 values, reduces Reuni by approximately $11 \%$ and does not adjust the inflation for the period, as well as disregards the expansion of the system. (Conselho Pleno da Andifes, 2017).

The budgetary and financial problems of public federal higher education institutions increase each year as a result of the policy of permanent fiscal adjustment. By projecting a reduction in the allocation of funds for public higher education over the next twenty years, as recommended by EC 95/2016 (Emenda Constitucional No. 95, 2016), the likelihood of the situation worsening is even greater. The other side of the policy of deepening the privatization and commodification of higher education is evidenced in the establishment of the new rules for FIES by Provisional Measure no. 785/2017 (Medida Provisória No 785, 2017), which divided the program into modalities, extinguishing the grace period and forcing students to start paying back the loan immediately upon receiving the degree. It also opened the possibility for private banks to fund higher education, ensuring that the capital participates in the profitable market of education.

\section{Final considerations}

The analysis of the data and documents presented shows that the bourgeois counterrevolution carries out systematic actions to reorganize its attacks to face the crises of capitalism and to conform minds and hearts to the bourgeois project of sociability. From 2003 to 2016, there was a counterrevolutionary process marked by the policy of class conciliation. In 2016 Brazil entered a new phase of preventive and prolonged counterrevolution led by the most aggressive and ultra-conservative fractions of the bourgeoisie in their agile, intense, and direct struggle in defense of economic and political interests. In this struggle, one of the main actions was the regression on rights of the working class, among them, the right of education and, particularly, higher education.

It is up to the working class to reorganize; offer solid criticism toward the conciliation policies, cooptation, and weakening of struggles; reaffirm the need for political actions against economic expropriation and the regression of workers' rights conquered throughout history; stand up advocating for public and free tuition education; and the allocation of public funds exclusively to public universities, as Florestan Fernandes defended throughout his activist intellectual leadership.

\section{References}

Antunes, R. (2005). A desertificação neoliberal no Brasil: Collor, FHC e Lula (2nd ed.). Campinas, Brazil: Autores Associados, 2005. Auditoria Cidadã da Dívida. (2011). A dívida pública consome quase metade dos recursos da União todos os anos! [Brochure]. Retrieved from https://www.auditoriacidada.org.br/wp-content/uploads/2015/04/Panfleto-Nacional_SP-2015-frente.pdf Auditoria Cidadã da Dívida. (2012). A divida pública é o centro dos problemas nacionais. Retrieved from https://auditoriacidada.org.br/ wp-content/uploads/2018/03/a-divida-publica-panfleto-3-18.pdf 
Auditoria Cidadã da Dívida. (2014). É por direitos: Vamos exigir auditoria da divida, que absorveu 40,30\% dos recursos federais em 2013, enquanto a saúde recebeu apenas 4,29\%, a educação 3,70\%, segurança 0,40\%, transportes 0,59\% e habitação 0,00\% [Archive Microsoft Word]. Retrieved from http://www.auditoriacidada.org.br/wp-content/uploads/2014/06/Panfleto-Manifestacoes-versao2014.docx

Auditoria Cidadã da Dívida. (2015a). Orçamento Geral da União [Chart]. Retrieved from https://www.auditoriacidada.org.br/wpcontent/uploads/2013/08/grafico-2015-2.pdf

Auditoria Cidadã da Dívida. (2015b). Panfleto Nacional [Brochure]. Retrieved from https://www.auditoriacidada.org.br/wp-content/ uploads/2015/04/Panfleto-Nacional_SP-2015-frente.pdf

Auditoria Cidadã Da Dívida. (2017). Consulta nacional sobre reformas e auditoria da dívida. Retrieved from https:// www.auditoriacidada.org.br/wp-content/uploads/2017/05/02-CONSULTA-NACIONAL-SOBRE-REFORMAS-1.pdf

Behring, E. R. (2003). Brasil em contra-reforma: Desestruturação do Estado e perda de direitos. São Paulo, Brazil: Cortez.

Coordenação da "Auditoria Cidadã da Dívida". (2004). Boletim Auditoria Cidadã da Dívida, 2004(9). Retrieved from https:// auditoriacidada.org.br/wp-content/uploads/2012/08/Boletim9.pdf

Coordenação da "Auditoria Cidadã da Dívida". (2005). Boletim Auditoria Cidadã da Dívida, 2005(11). Retrieved from https:// auditoriacidada.org.br/wp-content/uploads/2012/08/Boletim11.pdf

Coordenação da "Auditoria Cidadã da Dívida". (2006a). Boletim Auditoria Cidadã da Dívida, 2006(14). Retrieved from https:// auditoriacidada.org.br/wp-content/uploads/2012/08/Boletim14.pdf

Coordenação da "Auditoria Cidadã da Dívida". (2006b). Boletim Auditoria Cidadã da Dívida, 2006(16). Retrieved from https:// auditoriacidada.org.br/wp-content/uploads/2012/08/Boletim16.pdf

Coordenação da “Auditoria Cidadã da Dívida". (2008). Boletim Auditoria Cidadã da Dívida, 2008(18). Retrieved from https:// auditoriacidada.org.br/wp-content/uploads/2012/08/Boletim18.pdf

Coordenação da “Auditoria Cidadã da Dívida". (2009). Boletim Auditoria Cidadã da Dívida, 2009(19). Retrieved from https:// auditoriacidada.org.br/wp-content/uploads/2012/08/Boletim19.pdf

Coordenação da "Auditoria Cidadã da Dívida". (2010). Boletim Auditoria Cidadã da Dívida, 2010(20). Retrieved from https:// auditoriacidada.org.br/wp-content/uploads/2012/08/Boletim20.pdf

Emenda Constitucional No. 95, de 15 de Dezembro de 2016, Diário Oficial da União [D.O.U] de 15.12.2016. Retrieved from http:// www.planalto.gov.br/ccivil_03/constituicao/emendas/emc/emc95.htm

Lei No. 10.260, de 12 de julho de 2001. Diário Oficial da União [D.O.U] 13.7.2001. Retrieved from http://www.planalto.gov.br/ ccivil_03/LEIS/LEIS_2001/L10260.htm

Lei No. 11.096, de 13 de janeiro de 2005, Diário Oficial da União [D.O.U] 14.1.2005 Retrieved from http://www.planalto.gov.br/ ccivil_03/_Ato2004-2006/2005/Lei/L11096.htm

Lei No 12.202, de 14 de janeiro de 2010. Diário Oficial da União [D.O.U] 15.1.2010. Retrieved from http://www.planalto.gov.br/ ccivil_03/_Ato2007-2010/2010/Lei/L12202.htm

Lei No 12.513, de 26 de outubro de 2011. Diário Oficial da União [D.O.U] 27.10.2011. Retrieved from http://www.planalto.gov.br/ ccivil_03/_ato2011-2014/2011/lei/112513.htm

Lei No 13.005, de 25 de junho de 2014. Diário Oficial da União [D.O.U] 26.6.2014. Retrieved from http://www.planalto.gov.br/ ccivil_03/_ato2011-2014/2014/lei/113005.htm

Lei No 13.260, de 16 de março de 2016. Diário Oficial da União [D.O.U] 18.3.2016. Retrieved from http://www.planalto.gov.br/ ccivil_03/_Ato2015-2018/2016/Lei/L13260.htm

Medida Provisória No 785, de 6 de julho de 2017. Diário Oficial da União [D.O.U] 7.7.2017. Retrieved from http://www.planalto.gov.br/ ccivil_03/_Ato2015-2018/2017/Mpv/mpv785impressao.htm

Núcleo Mineiro da Auditoria Cidadão da Dívida. (2012). Minas Gerais não pode continuar pagando dívida ilegal à custa de sacrifício social. Retrieved from: https://www.auditoriacidada.org.br/wp-content/uploads/2012/08/13.02.12-Panfleto-ALMG.pdf

Portaria No 15, de $1^{\circ}$ de julho de 2014. Diário Oficial da União [D.O.U] 2.7.2014.

Retrieved from http://www.lex.com.br/legis_25699630_PORTARIA_NORMATIVA_N_15_DE_1_DE_JULHO_DE_2014.aspx

Coletivo de Estudos em Marxismo e Educação. (2016). PNE Plano Nacional de Educação 2014- 2024 : Novos elementos de pesquisa e de critica. Retrieved from http://www.colemarx.com.br/wp-content/uploads/2016/12/PNE_2014_2024_V_final.pdf

Conselho Pleno da Andifes. (2017, August 24). Nota à sociedade. Retrieved June 07, 2018, from http://www.andifes.org.br/52515-2 Dias, E. F. (2004). Traição ou lógica? Universidade e Sociedade, 13, 9-21. Retrieved from http://portal.andes.org.br/imprensa/publicacoes/ imp-pub-1002280985.pdf

Fernandes, F. (1976). A revolução burguesa no Brasil: Ensaio de interpretação sociológica (2nd.). Rio de Janeiro, Brazil: Zahar.

Fernandes, F. (1980). Brasil: Em compasso de espera. São Paulo, Brazil: Hucitec.

Fernandes, F. (1975). Capitalismo dependente e classes sociais na América Latina (2nd). Rio de Janeiro, Brazil: Zahar.

Fernandes, F. (1995). Em busca do socialismo: Últimos escritos \& outros textos. São Paulo, Brazil: Xamã.

Fernandes, F. (1991). O PT em movimento: contribuição ao I congresso do Partido dos Trabalhadores. São Paulo, Brazil: Cortez: Autores Associados. ok

Fernandes, F.(1968). Sociedade de classes e subdesenvolvimento. Rio de Janeiro, Brazil: Zahar, 1968. 
Fundação Ulysses Guimarães \& Partido do Movimento Democrático Brasileiro. (2015, october 29). Uma ponte para o futuro. Retrieved from https://www.fundacaoulysses.org.br/wp-content/uploads/2016/11/UMA-PONTE-PARA-O-FUTURO.pdf Fundação Ulysses Guimarães \& Partido do Movimento Democrático Brasileiro. (2016). A travessia social: uma ponte para o futuro. Retrieved from: https://www.fundacaoulysses.org.br/wp-content/uploads/2016/11/TRAVESSIA-SOCIAL-PMDB_LIVRETO_PNTE_ PARA O FUTURO.pdf

Granemann, S. (2003). A reforma da previdência do governo Lula: Argumentos e perspectiva de classe. Revista Outubro, 2003(9), 113-124. Retrieved from http://outubrorevista.com.br/wp-content/uploads/2015/02/Revista-Outubro-Edic\%CC\%A7a\%CC\%83o-9-Artigo-07.pdf Granemann, S. (2006). Para uma interpretação marxista da previdência privada (Doctoral thesis, Federal University of Rio de Janeiro, Rio de Janeiro, Brazil). Retrieved from http://livros01.livrosgratis.com.br/cp020126.pdf

Iasi, M. L. (2006). As metamorfoses da consciência de classe: o PT entre a negação e o consentimento. São Paulo, Brazil: Expressão Popular. Instituto Nacional de Estudos e Pesquisas Educacionais Anísio Teixeira. (2011). Censo da Educação Superior 2010: Divulgação dos principais resultados do Censo da Educação Superior 2010. Retrieved from http://download.inep.gov.br/educacao_superior/ censo_superior/documentos/2010/divulgacao_censo_2010.pdf

Instituto Nacional de Estudos e Pesquisas Educacionais Anísio Teixeira. (2016). Censo da Educação Superior 2016: Notas estatísticas. Retrieved from http://download.inep.gov.br/educacao_superior/censo_superior/documentos/2016/notas_sobre_o_censo_da_educacao_ superior_2016.pdf

Leher, R. (2010). Educação no governo de Lula da Silva: a ruptura que não aconteceu. In J. P. A. Magalhães et al., Os anos Lula: Contribuições para um balanço crítico 2003-2010 (2nd. pp. 369-412). Rio de Janeiro, Brazil: Garamond.

Lima, K. (2007). Contra-reforma na educação superior: de FHC a Lula. São Paulo, Brazil: Xamã.

Lima, K. (2015). Plano Nacional de Educação 2014-2024: nova fase do privatismo e da certificação em larga escala. Universidade e Sociedade, 24, 32-43. Retrieved from https://www.andes.org.br/img/midias/7642a1db844d305c70e26b4ee0b1a732_1548264588.pdf Minto, L. W. (2018). Educação superior no PNE (2014-2024): apontamentos sobre as relações público-privadas. Revista Brasileira de Educação, 23, 1-17. doi: 10.1590/s1413-24782018230011

Queiroz, V. (2015). Fundo de Financiamento Estudantil (FIES): uma nova versão do CREDUC. Universidade e Sociedade, $24,44-57$. Retrieved from https://www.andes.org.br/img/midias/7642a1db844d305c70e26b4ee0b1a732_1548264588.pdf

Sampaio Júnior, P. A. (2001). A natureza da burguesia brasileira em Florestan Fernandes. Dossiê Brasil. Retrieved from http:// www.fau.usp.br/docentes/depprojeto/c_deak/CD/3publ/01dossiebrasil/bib/saml-brg/index.html

Sampaio Júnior, P. A. (2017). Crônica de uma crise anunciada: crítica à economia política de Lula e Dilma. São Paulo, Brazil: SGAmarante.

Sampaio Júnior, P. A. (2012). "Vivemos um processo de reversão neocolonial". IHU On-Line, 12, 10-13. Retrieved from http:// www.ihuonline.unisinos.br/media/pdf/IHUOnlineEdicao392.pdf ok

\section{Notas}

1 For more on the particularities of the 2008 world economic crisis, see Sampaio Júnior (2017) (available in Portuguese), chapters 9 (Crise e barbárie [Crisis and barbarism]) and 11 (Metástase da crise e aprofundamento da reversão neocolonial [Metastasis of the crisis and deepening of neocolonial return]).

2 During the period between 2003 and 2016, a narrative that there was a new phase of development - the new developmentalism gained space. It was a narrative characterized by the relative increase in consumption through the working class. However, this article agrees with Sampaio Júnior (2012, p. 12, our translation) in his statement “the neo-developmentalism is a 'hollow' label. It is more of a propaganda of Lula and Dilma governments to show some distance from the governments of Cardoso, than a doctrine that guides the state's actions."

3 Law 13260/2016(Anti-terrorism law)(Lei No 13.260,2016) is one of the most evident references regarding the criminalization of social movements during the period from 2011 to 2016).

4 Granemann $(2003,2006)$ provides a deeper analysis on the Brazilian social security counterreform.

\section{Kátia Regina de Souza Lima}

katiaslima@globo.com

$\mathrm{PhD}$ in Education from the Graduate Program in Education of the Fluminense Federal University (UFF). Associated Professor at the School of Social Work from the Department of Social Work of Niterói and at the Graduate Program in Social Work and Regional Development of the UFF.

\section{UFF}

Campus do Gragoatá 
Rua Prof. Marcos Waldemar de Freitas Reis, s/n, bloco E - São Domingos

Niterói - Rio de Janeiro - Brasil

CEP: 24.210-201

\begin{abstract}
Acknowledgement
I am thankful to the Research Group on Education and Social Work (GEPESS) of the Fluminense Federal University for the opportunity to collectively build creative and critic knowledge.
\end{abstract}

Financial support

Not applicable

\section{Contributions of authors}

Not applicable
Approval by the Ethical Committee and consent to participate

Not applicable

\section{Consent to publish}

Not applicable

Conflict of interest

Not applicable 